\title{
Primary Endometrial High Grade Neuroendocrine Carcinoma: A Case Report with Cytological, Histopathological and Immunohistochemical Features
}

\author{
Kazuhiro Kobayashi' ${ }^{1}$, Masashi Matsuyama², Fumimasa Etori², Naomi Kawaguchi'2, \\ Kyoko Nambu'2, Asuka Sekiya², Yuka Hiraku³, Kazushige Yamamoto, \\ Naoki Watanabe ${ }^{2}$, Tetsuya Yamada ${ }^{4}$, Takuji Tanaka ${ }^{1,2^{*}}$ \\ ${ }^{1}$ Department of Tumor Pathology, Gifu University Graduate School of Medicine, Gifu City, Japan \\ ${ }^{2}$ Department of Diagnostic Pathology (DDP) \& Research Center of Diagnostic Pathology (RC-DiP), Gifu \\ Municipal Hospial, Gifu City, Japan \\ ${ }^{3}$ Department of Obstetrics \& Gynecology, Gifu Municipal Hospial, Gifu City, Japan \\ ${ }^{4}$ Department of Diagnostic Pathology, Kizawa Memory Hospital, Minokamo City, Japan \\ Email: takutt@gmhosp.gifu.gifu.jp
}

Received 15 November 2014; revised 25 December 2014; accepted 2 January 2015

Copyright (C) 2015 by authors and Scientific Research Publishing Inc.

This work is licensed under the Creative Commons Attribution International License (CC BY).

http://creativecommons.org/licenses/by/4.0/

C) (i) Open Access

\section{Abstract}

An 84-year-old woman suffered from post-menopausal genital bleeding for 3 months. Based on the endometrial cytological findings (suggestive of high grade neuroendocrine carcinoma) showing that there were rosette-like and cord-like structures consisting of small rounded tumor cells with oval nuclei and scanty cytoplasm, radical hysterectomy was performed. Histopathological and immunohistochemical examinations on the operated specimens revealed primary high grade neuroendocrine carcinoma of the endometrium. Despite the extensive treatment against the malignancy, the patient died due to widespread metastases after 5 months after the surgery and autopsied.

\section{Keywords}

Endometrium, High Grade Neuroendocrine Carcinoma, Undifferentiated Carcinoma, Neuroendocrine Cells

\footnotetext{
${ }^{*}$ Corresponding author.

How to cite this paper: Kobayashi, K., Matsuyama, M., Etori, F., Kawaguchi, N., Nambu, K., Sekiya, A., Hiraku, Y., Yamamoto, K., Watanabe, N., Yamada, T. and Tanaka, T. (2015) Primary Endometrial High Grade Neuroendocrine Carcinoma: A Case Report with Cytological, Histopathological and Immunohistochemical Features. Open Journal of Pathology, 5, 1-7. http://dx.doi.org/10.4236/ojpathology.2015.51001
} 


\section{Introduction}

High grade neuroendocrine carcinoma (HGNEC) is a well-known aggressive epithelial malignancy that occurs predominantly in the lung. HGNEC also occurs in the female genital tract, most commonly in the cervix [1]-[3]. However, primary HGNEC of the endometrium is quite rare [1]-[3]. Based on the cases reported, the mean age at diagnosis is 59 years (range 23 - 87 years) [1]. No risk factors for endometrial HGNEC have been identified so far. Abnormal vaginal bleeding is the most frequent presenting symptom. In some patients, however, the presentation of endometrial HGNEC was related to symptomatic metastases [4], paraneoplastic syndromes such as retinopathy [5], or to Cushing syndrome due to ectopic ACTH production [6].

Although histopathologic and cytologic features of HGNEC developed in a variety of tissues including lung were well-documented, only a few cases of primary endometrial HGNEC were documented. Here we report a case of primary HGNEC of the endometrium with cytological, histopathological and immunohistochemical features. Pathogenesis of this rare malignancy was also discussed.

\section{Case Presentation}

On March 27, 2012, an 84-year-old Japanese woman suffering from post-menopausal bleeding presented our hospital for diagnosis and care. She received an anti-coagulant Warfarin because of brain infarction and atrial fibrillation as her past history. At presentation, physical examination and the results of routine serum biochemistry did not show any abnormalities except for abnormal vaginal bleeding. Although cervical and endometrial cytology was negative at admission, MRI (Figure 1$)$ and ultrasound examinations revealed a large tumor $(5.0 \times$ $4.7 \times 3.2 \mathrm{~cm}$ ) in the posterior wall of her uterus. Subsequent re-examination of endometrial cytology and biopsy revealed HGNEC of the uterus. There were no abnormalities in other organs including lung.

On the cytologic specimens from endometrium, we observed that there were many small round tumor cells possessing round and oval nuclei with coarse chromatin and inconspicuous nucleoli (Figure 2(a)). They have scanty cytoplasm. Rosette-like and cord-like structures of tumor cells were also noted (Figure 2(b)). These findings showed characteristics of HGNEC developed in the endometrium. Histopathology (Figure 3(a) and Figure 3(b)) of the biopsy specimens confirmed the cytological diagnosis.

Immediately after the cytological diagnosis of endometrial HGNEC, she underwent surgical therapy, including radical hysterectomy, bilateral salpingo-oophorectomy and pelvic lymphadenectomy. Macroscopic examination of the resected uterus revealed a bulky exophytic and hemorrhagic mass $(13 \times 9.5 \mathrm{~cm})$ that infiltrated more than half of myometrial wall and uterine cervix (Figure 4). Pelvic washing cytology was negative for invasive carcinoma cells. The post-operative stage was clinically defined as stage II. There was no evidence of distant metastases at this time. Histopathological examination using hematoxylin and stain of the endometrial tumor revealed dissociated atypical small tumor cells (Figure 5(a)). Morphologically and structurally, small cell component suggested neuroendocrine features. The tumor cells had round and monomorphic nuclei (Figure 5(b)). Round tumor cells with scanty cytoplasm were mostly small, but a few intermediate in size. Immunohistochemical investigation using an autostaining system (VENTANA) provided strong evidence for the neuroendocrine
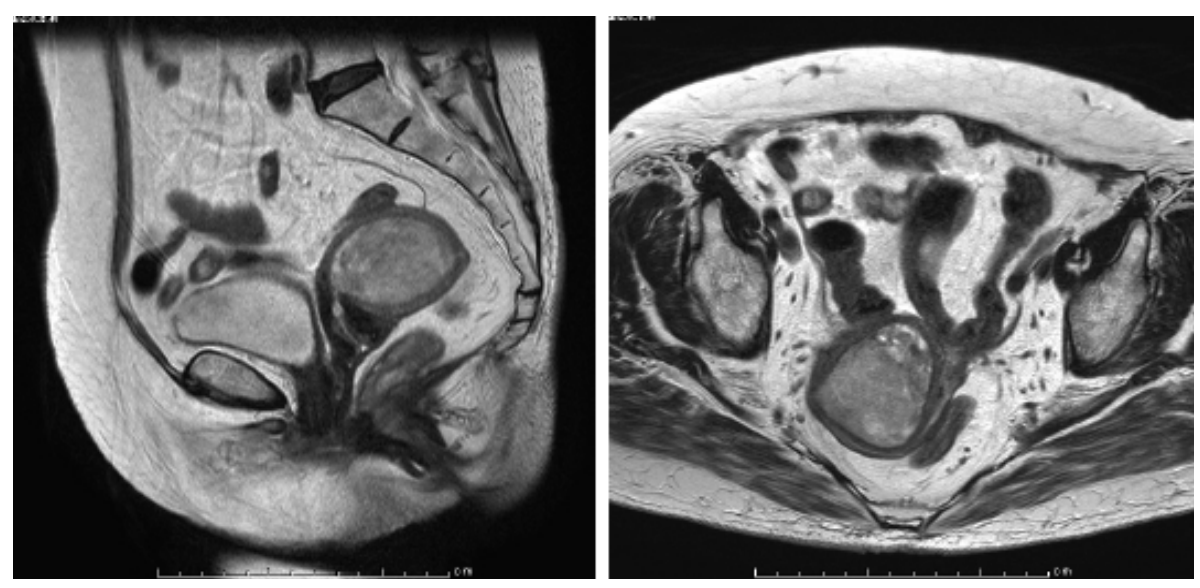

Figure 1. MRI images show a large tumor measuring $5.0 \times 4.7 \times 3.2 \mathrm{~cm}$ in the uterine cavity. 


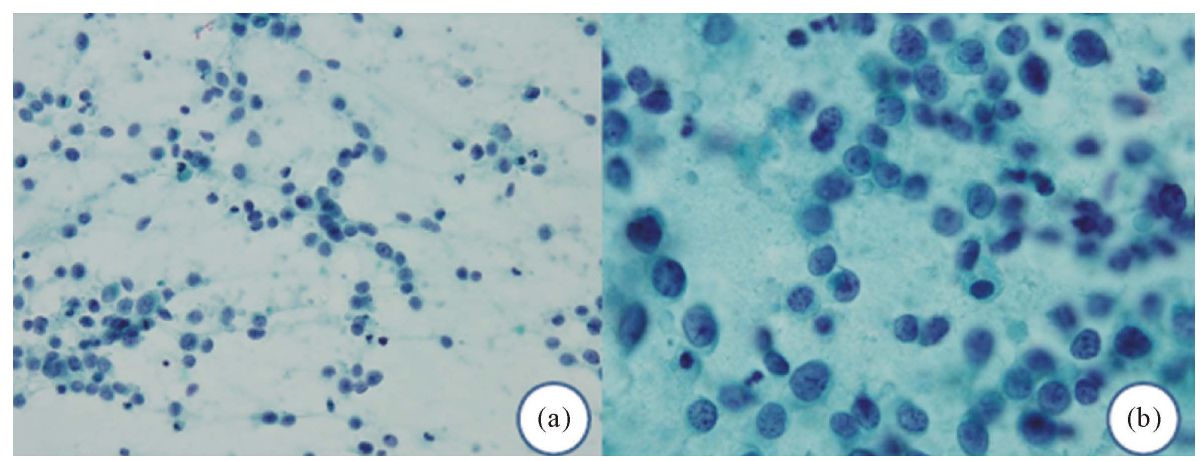

Figure 2. Endometrial cytology indicates (a) small neoplastic cells with scanty cytoplasm and (b) rosette-like structure of tumor cells. Papanicolaou stain. Original magnifications, (a) $\times 100$ and $(\mathrm{b}) \times 400$.

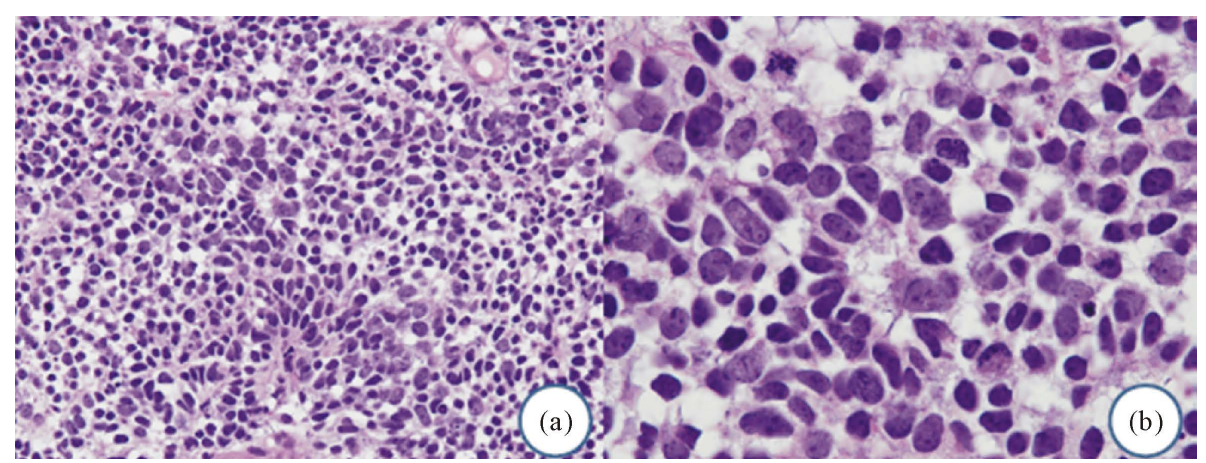

Figure 3. Histopathology of the endometrial biopsy specimens. (a) Tumor cells are small and intermediate in size; (b) In some parts, tumor cells show rosette-like structure as seen in the cytologic specimens. (a) and (b): H \& E stain. Original magnifications, (a) $\times 200$ and (b) $\times 400$.
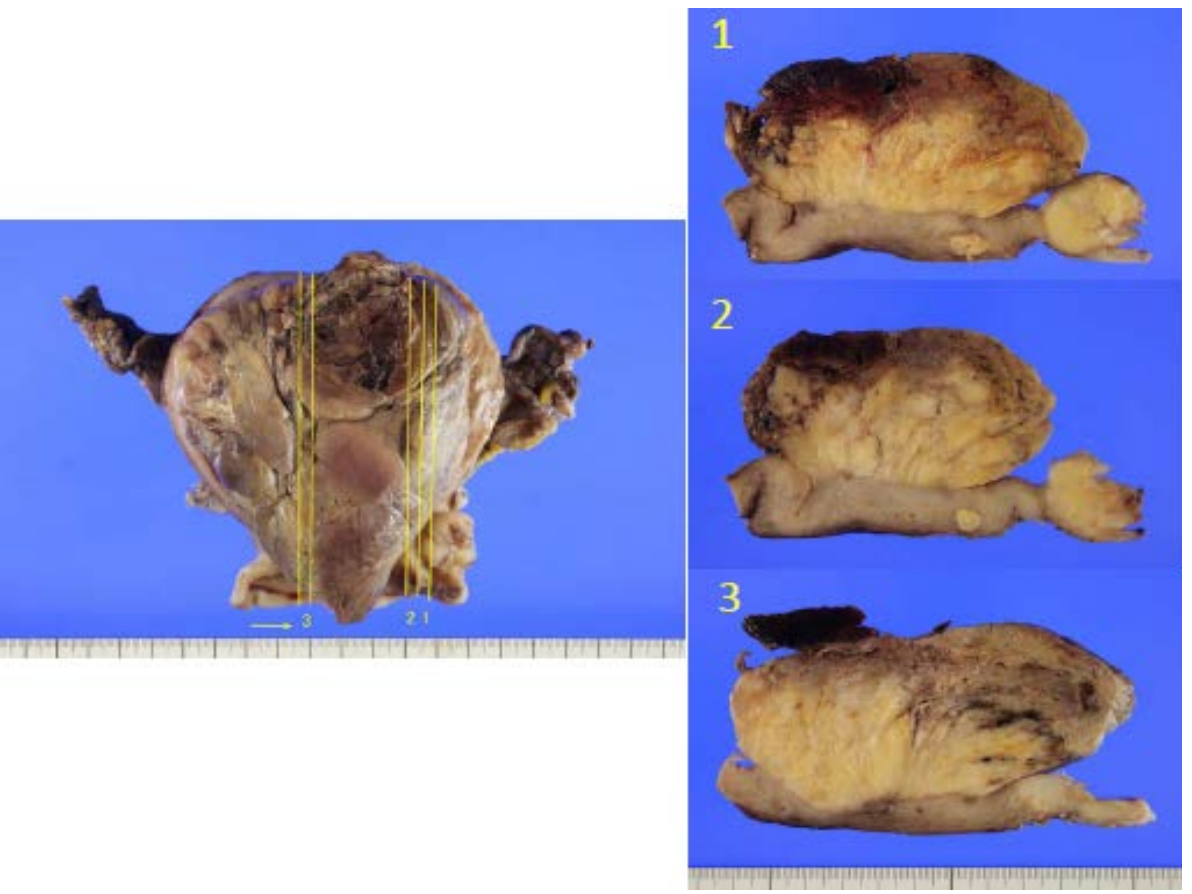

Figure 4. Macroscopic view of the uterus where a large tumor with hemorrgage is present. Note the tumor invades the muscular layer and uterine cervix. 
characteristics of the tumor cells. The neoplastic cells exhibited positive immunoreactivity for CD56 (Figure 6(a)) and synaptophysin (Figure 6(b)), but were negative for chromogranin A, CD10, carcinoembryonic antigen, CK7, CK20, estrogen receptor, and progesterone receptor. The proliferation rate estimated by immunoreactivity against the MIB-1 (Ki-67) antibody was nearly 70\% (Figure 6(c)). In addition, a few of non-tumorous endometrial gland cells are positive for CD56 (Figure 6(d)). Following the final pathologic review, a pT2, poorly differentiated HGNEC of the endometrium was identified.

No further treatments were performed, according to the patient's intention. However, two months after the operation, recurrence in the vagina stump was noticed. Although radiation therapy with a total dose of $50 \mathrm{~Gy}$

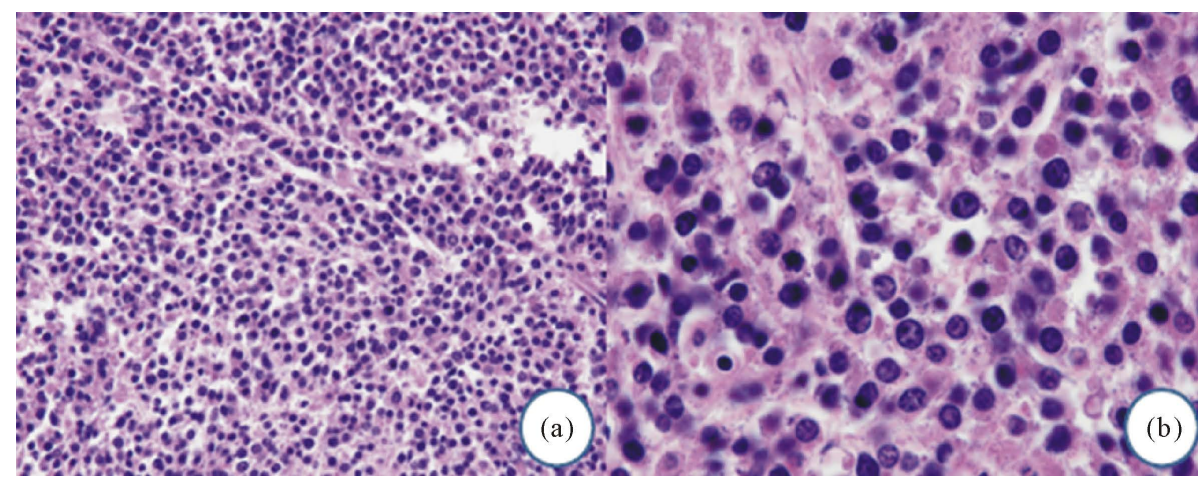

Figure 5. Histopathology of HGNEC in the endometrium. (a) HGNEC cells arrange cordlike structures and monotonously proliferate; (b) HGNEC have round nuclei scanty cytoplasm. (a) and (b): H \& E stain. Original magnifications, (a) $\times 400$ and (b) $\times 1000$.

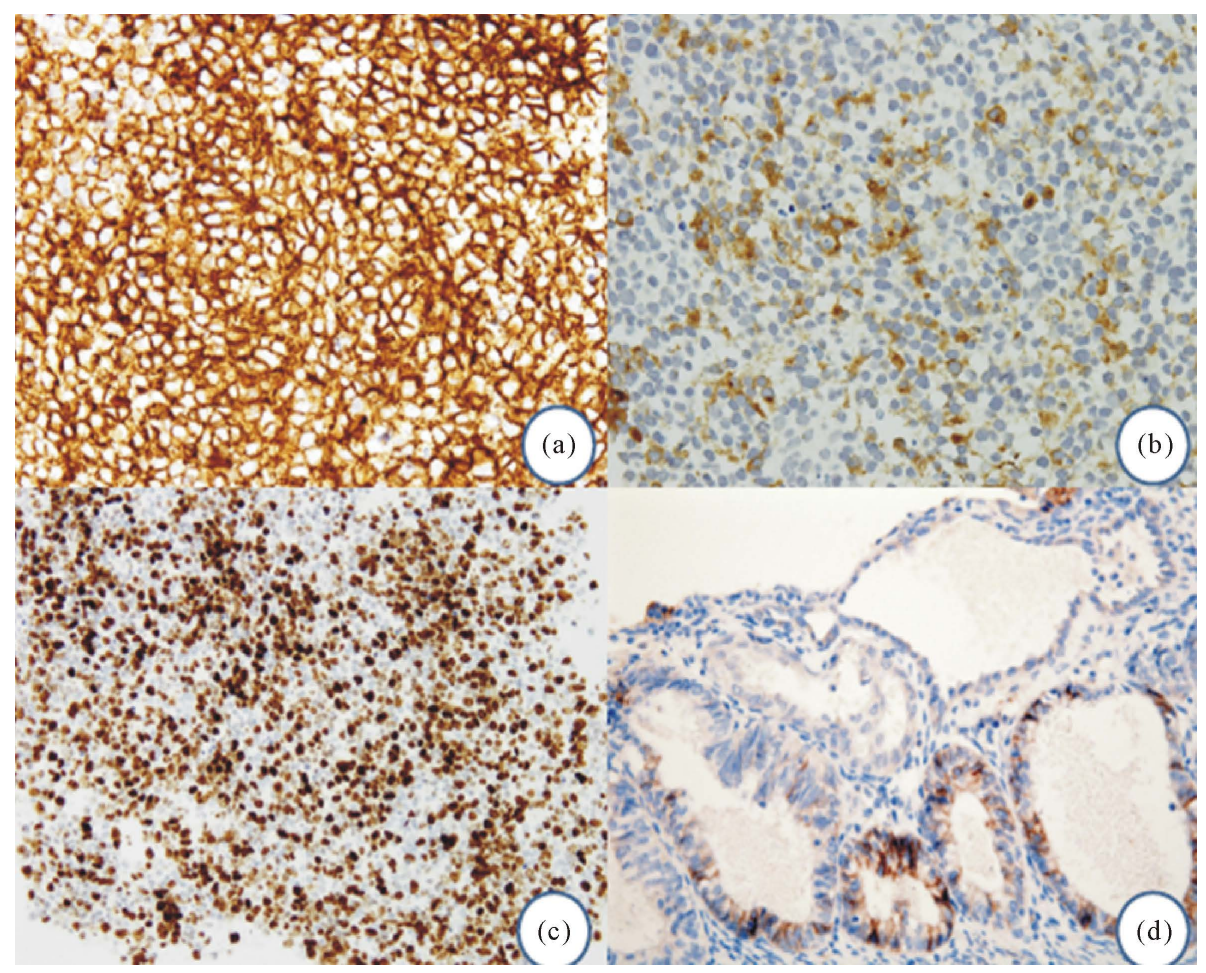

Figure 6. Immunohistochemistry of the tumor and non-neoplastic endometrial glands. The tumor cells were strongly immunoreactive for (a) CD56 and weakly immunoreactive for (b) synaptophysin; (c) Approximately $70 \%$ of cancer cells are positive for MIB-1; (d) Some non-neoplastic cells of endometrial glands are positive for CD 56. (a) and (d) CD56 immunohistochemistry; (b) Synaptophysin immunohistochemistry; and (c) MIB-1 immunohistochemistry. Original magnifications (a), (b), (c) and (d) $\times 400$. 
reduced the size of the recurrent vaginal tumor, metastases of para-aortic lymph nodes were found by the CT examination. The patient died five months after the operation due to wide-spread of metastases, and autopsy was performed. Our autopsy findings confirmed a disseminated endometrial small endocrine cell carcinoma with strong infiltration and wide-spread of cancer cells in a variety of tissues, including omentum, small bowel mesentery, the sigmoid colon, lung, liver and lymph nodes (para-aortic, common iliac artery, tracheal bifurcation and mediastinum).

\section{Discussion}

The most common site of developing HGNEC is the lung, although less frequently, it can also occur in a variety of sites including the gastrointestinal tract. Extra-pulmonary HGNEC comprises less than $4 \%$ of all HGNECs. The rare occurrence of HGNEC in the genital organs is known, and most of the cases were developed in the uterine cervix and ovary [1]-[3]. Primary endometrial HGNEC is an extremely rare [1]-[3], accounting for approximately $0.8 \%$ of all endometrial carcinomas [7]. Approximately 80 cases of endometrial HGNEC have been reported in the English-language literature [1].

This tumor has a high propensity for systemic spread and poor prognosis. Therefore, endometrial HGNEC is frequently diagnosed at an advanced stage and has a poor prognosis [1]. As noted in this case, the most common presenting sign of HGNEC is definitely a peri- or post-menopausal vaginal bleeding, although the occurrence of tongue base bleeding was reported as the first manifestation of disseminated HGNEC [8]. Our case (84-year-old) was much older than the mean age (59 years) at diagnosis of endometrial HGNEC, but her symptom was similar to that reported previously. Our case did not present paraneoplastic or Cushing syndrome [5] [6].

Endometrial cytological examination is a useful and minimally-invasive tool for detecting endometrial malignancies [9], including HGNEC, as reported here. Due to the rarity of HGNEC, only two cytological reports of endometrial HGNEC have been documented in the English literature [10] [11].

Extra-pulmonary HGNECs share histopathological and immunohistochemical features with their pulmonary counterpart. According to the latest WHO classification [12], endometrial HGNEC is defined as "an endometrial carcinoma resembling small cell lung cancer". The diagnostic criteria of endometrial HGNEC defined by van Hoeven et al. [13] include a dense sheet-like growth of small to intermediate tumor cells with at least one positive neuroendocrine marker and unequivocal evidence of its endometrial origin. It is not unusual to observe a component of HGNEC associated with other uterine malignancies, including endometrioid adenocarcinoma, serous adenocarcinoma and carcinosarcoma [13] [14]. Positive rate of immunohistochemical expression of neuroendocrine markers of neuron-specific enolase (85\%), chromogranin A (46\%), synaptophysin (56\%), Leu-7 (80\%) and CD56 (100\%) was reported in endometrial HGNEC [13] [15]. Expression of broad-spectrum cytokeratins is usually present [14]. To make final diagnosis of primary endometrial HGNEC, we should confirm the differential diagnosis, such as HGNEC metastatic to the endometrium, particularly spread from the cervix, and other endometrial carcinomas (carcinosarcomas, stromal sarcomas and primitive neuroectodermal tumors of the uterus), which contain argyrophil cells. Undifferentiated and dedifferentiated endometrioid carcinomas also frequently resemble HGNEC [16] [17]. Detailed examinations of our case, including immunohistochemistry, revealed primary endometrial small endocrine cell carcinoma.

As to the histogenesis of primary endometrial HGNEC, the origin is controversial. It was assumed that this malignancy arises from neuroendocrine cells in the Amine Precursor Up-take and Decarboxylation (APUD) system [18] [19]. The presence of argyrophil cells in normal endometrial glands [20] strengthens the hypothesis. Indeed, a few of non-neoplastic endometrial gland cells are positive for CD56. However, to date, it is thought that the origin of endometrial HGNEC is either a totipotent stem cell capable of differentiating into a variety of cell types, or that components of HGNEC arise as a late-stage phenomenon in the genetic progression of carcinomas [18]. In a recent study on massively parallel sequencing of small-cell lung cancer, one patient had a lung adenocarcinoma resected three years before the diagnosis with endometrial HGNEC. Interestingly, the authors found the same TP53 mutation in both tumors, while the RB1 mutation was restricted to the small cell component [21]. This suggests possible trans-differentiation of adenocarcinoma cells to HGNEC cells.

\section{Acknowledgements}

This work was partly supported by a Grant-in-Aid for the 3rd Terms Comprehensive 10-Year Strategy for Cancer Control from the Ministry of Health, Labour and Welfare of Japan. 


\section{Competing Interests}

The authors declare that they have no competing interests.

\section{References}

[1] Atienza-Amores, M., Guerini-Rocco, E., Soslow, R.A., Park, K.J. and Weigelt, B. (2014) Small Cell Carcinoma of the Gynecologic Tract: A Multifaceted Spectrum of Lesions. Gynecologic Oncology, 134, 410-418. http://dx.doi.org/10.1016/j.ygyno.2014.05.017

[2] Crowder, S. and Tuller, E. (2007) Small Cell Carcinoma of the Female Genital Tract. Seminars in Oncology, 34, 57-63. http://dx.doi.org/10.1053/j.seminoncol.2006.10.028

[3] Eichhorn, J.H. and Young, R.H. (2001) Neuroendocrine Tumors of the Genital Tract. American Journal of Clinical Pathology, 115 (Suppl 1), S94-112.

[4] Katahira, A., Akahira, J., Niikura, H., Ito, K., Moriya, T., Matsuzawa, S., Makinoda, S., Oda, T., Fujiwara, K. and Yaegashi, N. (2004) Small Cell Carcinoma of the Endometrium: Report of Three Cases and Literature Review. International Journal of Gynecological Cancer, 14, 1018-1023. http://dx.doi.org/10.1111/j.1048-891X.2004.14545.X

[5] Campo, E., Brunier, M.N. and Merino, M.J. (1992) Small Cell Carcinoma of the Endometrium with Associated Ocular Paraneoplastic Syndrome. Cancer, 69, 2283-2288. http://dx.doi.org/10.1002/1097-0142(19920501)69:9<2283::AID-CNCR2820690913>3.0.CO;2-V

[6] Sato, H., Kanai, G., Kajiwara, H., Itoh, J. and Osamura, R.Y. (2010) Small-Cell Carcinoma of the Endometrium Presenting as Cushing's Syndrome. Endocrine Journal, 57, 31-38. http://dx.doi.org/10.1507/endocrj.K09E-212

[7] van Meerbeeck, J.P., Fennell, D.A. and De Ruysscher, D.K. (2011) Small-Cell Lung Cancer. Lancet, 378, $1741-1755$. http://dx.doi.org/10.1016/S0140-6736(11)60165-7

[8] Marioni, G., Savastano, M., Mattiello, L., Koussis, H., Carpene, S., Marino, F. and Staffieri, A. (2007) Tongue Base Metastasis from Neuroendocrine Endometrial Small Cell Carcinoma. American Journal of Otolaryngology, 28, 284287. http://dx.doi.org/10.1016/j.amjoto.2006.09.011

[9] Sakamoto, H., Takenaka, M., Ushimaru, K. and Tanaka, T. (2012) Use of Liquid-Based Cytology (LBC) and Cell Blocks from Cell Remnants for Cytologic, Immunohistochemical, and Immunocytochemical Diagnosis of Malignancy. Open Journal of Pathology, 2, 58-65. http://dx.doi.org/10.4236/ojpathology.2012.23012

[10] Ishida, M., Iwamoto, N., Nakagawa, T., Kaku, S., Iwai, M., Kagotani, A., Takahashi, K., Murakami, T. and Okabe, H. (2014) Small Cell Carcinoma of the Endometrium: A Case Report with Emphasis on the Cytological Features. International Journal of Clinical and Experimental Pathology, 7, 3332-3337.

[11] Proca, D., Keyhani-Rofagha, S., Copeland, L.J. and Hameed, A. (1998) Exfoliative Cytology of Neuroendocrine Small Cell Carcinoma of the Endometrium. A Report of Two Cases. Acta Cytologica, 42, 978-982. http://dx.doi.org/10.1159/000331980

[12] Kurman, R.J., Carcangiu, M.L., Herrington, C.S. and Young, R.H., Eds. (2014) WHO Classification of Tumours of Female Reproductive Organs. IARC Press, Lyon.

[13] van Hoeven, K.H., Hudock, J.A., Woodruff, J.M. and Suhrland, M.J. (1995) Small Cell Neuroendocrine Carcinoma of the Endometrium. International Journal of Gynecological Pathology, 14, 21-29. http://dx.doi.org/10.1097/00004347-199501000-00005

[14] Huntsman, D.G., Clement, P.B., Gilks, C.B. and Scully, R.E. (1994) Small-Cell Carcinoma of the Endometrium. A Clinicopathological Study of Sixteen Cases. The American Journal of Surgical Pathology, 18, 364-375. http://dx.doi.org/10.1097/00000478-199404000-00005

[15] Albores-Saavedra, J., Martinez-Benitez, B. and Luevano, E. (2008) Small Cell Carcinomas and Large Cell Neuroendocrine Carcinomas of the Endometrium and Cervix: Polypoid Tumors and Those Arising in Polyps May Have a Favorable Prognosis. International Journal of Gynecological Pathology, 27, 333-339. http://dx.doi.org/10.1097/PGP.0b013e31815de006

[16] Tafe, L.J., Garg, K., Chew, I., Tornos, C. and Soslow, R.A. (2010) Endometrial and Ovarian Carcinomas with Undifferentiated Components: Clinically Aggressive and Frequently Underrecognized Neoplasms. Modern Pathology, 23, 781-789. http://dx.doi.org/10.1038/modpathol.2010.41

[17] Silva, E.G., Deavers, M.T. and Malpica, A. (2007) Undifferentiated Carcinoma of the Endometrium: A Review. Pathology, 39, 134-138. http://dx.doi.org/10.1080/00313020601159494

[18] Frazier, S.R., Kaplan, P.A. and Loy, T.S. (2007) The Pathology of Extrapulmonary Small Cell Carcinoma. Seminars in Oncology, 34, 30-38. http://dx.doi.org/10.1053/j.seminoncol.2006.11.017

[19] Pearse, A.G. (1979) The Diffuse Endocrine System and the Implications of the APUD Concept. International Surgery, 
64, 5-7.

[20] Sivridis, E., Buckley, C.H. and Fox, H. (1984) Argyrophil Cells in Normal, Hyperplastic, and Neoplastic Endometrium. Journal of Clinical Pathology, 37, 378-381. http://dx.doi.org/10.1136/jcp.37.4.378

[21] Peifer, M., Fernandez-Cuesta, L., Sos, M.L., George, J., Seidel, D., Kasper, L.H., Plenker, D., Leenders, F., Sun, R., Zander, T., Menon, R., Koker, M., Dahmen, I., Muller, C., Di Cerbo, V., Schildhaus, H.U., Altmuller, J., Baessmann, I., Becker, C., de Wilde, B., Vandesompele, J., Bohm, D., Ansen, S., Gabler, F., Wilkening, I., Heynck, S., Heuckmann, J.M., Lu, X., Carter, S.L., Cibulskis, K., Banerji, S., Getz, G., Park, K.S., Rauh, D., Grutter, C., Fischer, M., Pasqualucci, L., Wright, G., Wainer, Z., Russell, P., Petersen, I., Chen, Y., Stoelben, E., Ludwig, C., Schnabel, P., Hoffmann, H., Muley, T., Brockmann, M., Engel-Riedel, W., Muscarella, L.A., Fazio, V.M., Groen, H., Timens, W., Sietsma, H., Thunnissen, E., Smit, E., Heideman, D.A., Snijders, P.J., Cappuzzo, F., Ligorio, C., Damiani, S., Field, J., Solberg, S., Brustugun, O.T., Lund-Iversen, M., Sanger, J., Clement, J.H., Soltermann, A., Moch, H., Weder, W., Solomon, B., Soria, J.C., Validire, P., Besse, B., Brambilla, E., Brambilla, C., Lantuejoul, S., Lorimier, P., Schneider, P.M., Hallek, M., Pao, W., Meyerson, M., Sage, J., Shendure, J., Schneider, R., Buttner, R., Wolf, J., Nurnberg, P., Perner, S., Heukamp, L.C., Brindle, P.K., Haas, S. and Thomas, R.K. (2012) Integrative Genome Analyses Identify Key Somatic Driver Mutations of Small-Cell Lung Cancer. Nature Genetics, 44, 1104-1110. http://dx.doi.org/10.1038/ng.2396 
Scientific Research Publishing (SCIRP) is one of the largest Open Access journal publishers. It is currently publishing more than 200 open access, online, peer-reviewed journals covering a wide range of academic disciplines. SCIRP serves the worldwide academic communities and contributes to the progress and application of science with its publication.

Other selected journals from SCIRP are listed as below. Submit your manuscript to us via either submit@scirp.org or Online Submission Portal.
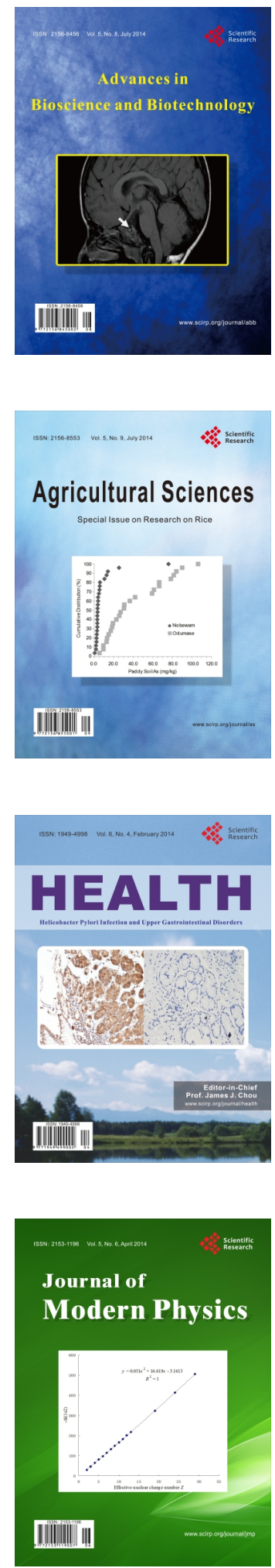
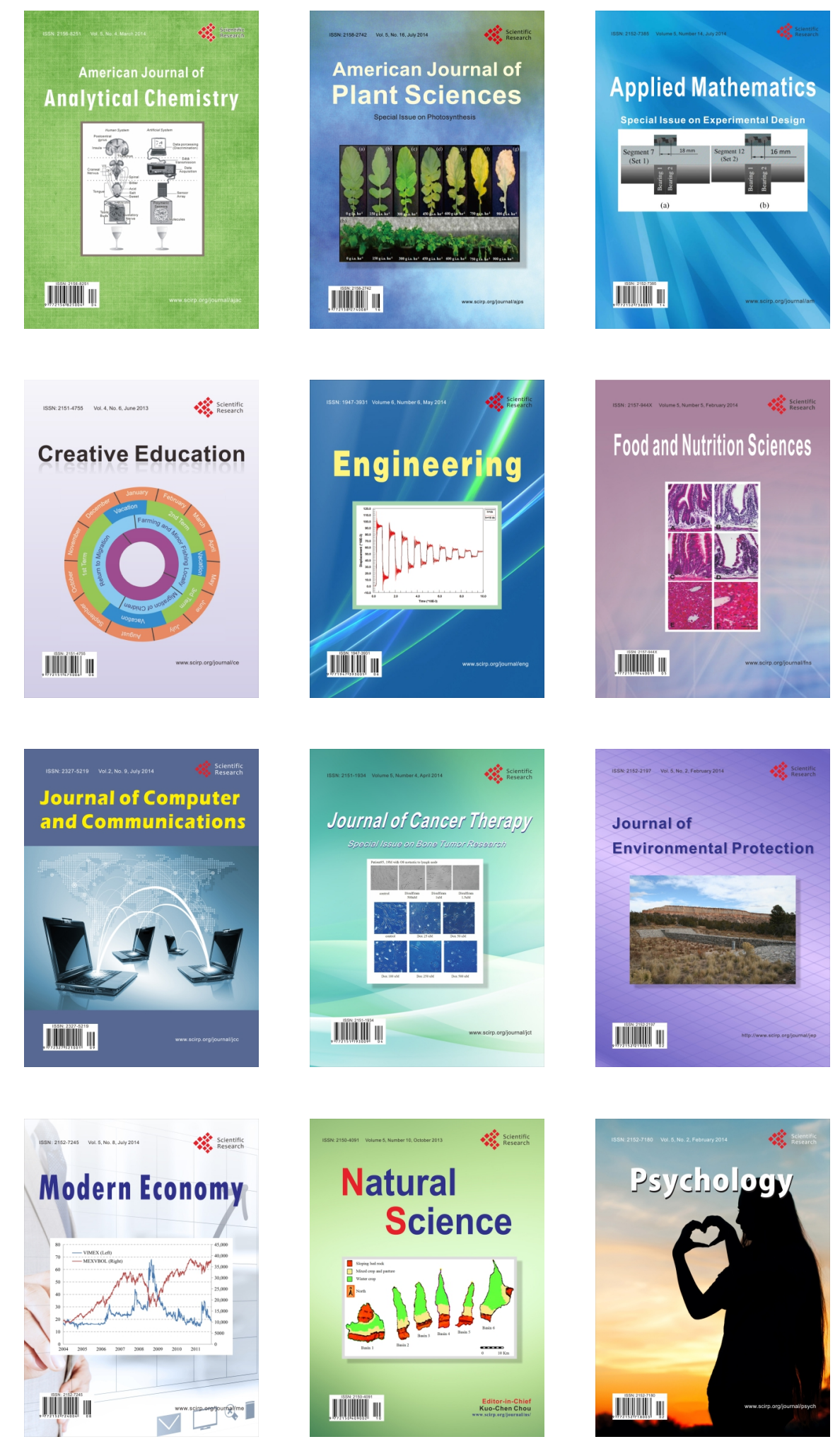